Borsodi L. László

Márton Áron Főgimnázium Magyar Nyelv és Irodalom Katedra, Csíkszereda

\title{
A költői nyelv haláltánca
}

\section{Baka István Halál-boleró címü versciklusáról ${ }^{1}$}

Papp Ágnes Klárának a szerepversekre és Nagy Gábornak a Baka István költészete korszakolására vonatkozó fogalomhasználatát alapul véve az látható, hogy míg az egyes köteteket tekintve az összegzó és új poétikai utakat nyitó Égtájak célkeresztjének az új versei a Farkasok órájával alkotják az újabb, a második pályaszakaszt, a Tájkép fohásszal címú gyújteményes kötet alapján árnyalva a ciklusokból épitkezó költészet szakaszolását, úgy vélem, a Halál-boleró és a Tájkép fohásszal címú ciklusok mind a versnyelv, mind a szerepjátszás tekintetében átmenetet képeznek a Döblinggel

lezáruló cikluskompozíciók és a Liszt Ferenc éjszakái, $a$ Yorick monológjai, $a$ Farkasok órája és Az Apokalipszis szakácskönyvéből címú ciklusok között. Elókészítik, poétikailag megalapozzák a szigorú metaforarendszert fellazító, a zaklatottabb, hosszabb lélegzetvételú groteszk-ironikus versnyelvet is, amely majd Baka maszklirájának a megváltozását is jelenti: az egyszeri maszkversek helyett teljes emberi

sorsot láttató szerepversciklusok jelennek meg, és felerósödik az apokaliptikus hang (Papp, 1996, 78. o.; Nagy, 2001, 14. o.; Vörös, 1997, 183. о.).

A Halál-boleró és a Tájkép fohásszal jelzik azt a kettősséget, amely Baka költői pályájának nem látványos, de határozott átalakulását jelenti: egyrészt továbbviszik ennek a költészetnek a halállal való eljegyzettségét, az apokaliptikusra hangolt kultúra terrénumait, rálelve másrészt a nyelv uralmát és a nyelvet mint egyetlen lehetséges, élhető létet jelentő szonettre, valamint arra a groteszk-ironikus, a metaforák rendszerének zártságát fellazító versnyelvre, amely e költészet szerves fejlödésének köszönhetően új poétikai dimenzióban, a fiktív alakokat felsorakoztató, átíró-újrateremtő, ciklusnyi szerepverseket eredményező költői szólamokban teljesedik ki.

A Halál-boleró a kötet korábbi ciklusaihoz hasonlóan címével nemcsak kijelöli a beszédhelyzetet, megteremtve a szerepjáték feltételeit, és ezen feltételek egyikeként a ciklus címadó versével keretbe helyezve a kompozíció egészét, hanem a nyelv - annak képszerü viselkedésével kapcsolatba hozható - önreflexív képességét is aktivizálja, felhívva a figyelmet, hogy a ciklusban a halál elsősorban nem a költői beszéd tárgya, hanem az azt meghatározó minőség, a költői nyelv létmódja. A halál bolerózik, azaz költészetet teremt, át- és újraír, így a címbeli kép a vers- és ciklusszerkezetet, sőt az egész költészetet alkotó cikluskompozíciót is metaforizál(hat)ja. A boleró természete szerint az egymást követő versek, ciklusok egymás variációi, felerösítései, átértelmezései, olyan költészettörténés, amelynek során a korábbi müvek - nemcsak a Baka-költészet szövegei, hanem a tágabb értelemben vett (irodalmi, müvészeti, történelmi stb.) hagyomány - motívumai, kompozíciós eljárásai, esztétikai minőségei, szerepváltozatai, -szólamai állandóan 
visszatérnek úgy, hogy mindig újabb aspektusokkal, értelmezési lehetőségekkel egészülnek ki, gazdagodnak, egyetlen nagy harmóniát, Baka polifonikus költészetét eredményezve. $^{2}$ Ez az esztétikai gazdagság a halál kultúrája révén teremtődik, amely maga is nyelv által teremtett. ${ }^{3}$ Amennyiben a költői nyelv révén válik hozzáférhetővé élet,

Amennyiben a költối nyelv révén válik hozzáférhetôvé élet, halál, világ, önértés stb., akkor a haláltánc müfajához köthetó Halál-boleróban és általában a haláltánc regiszterében megszólaló Baka-költészetben a kultúra, az irodalom különbözó doméniumaiba való alászállás a lét határaival, hiábavalóságá-

val szembesit, ugyanakkor

ennek a világnak a szépség megtapasztalását lehetóvé tevó képei, szerepjátékai arra hivják fel a figyelmet, hogy az igy keletkezó vers, kultúra érték, amely az értéktelen vagy a kétségbeejtó felmutatásával azt állítja: az alkotás, a költói nyelv a létmegértés és -felejtés egyetlen lehetséges közege, amely beavathat a létezés titkába; olyan univerzum, amely szembesit a világ természetével. Ez a szembesülés egyszerre létgazdagitó, katartikus kaland és a különféle szerepekben artikulálódó fájdalmas pokoljárás egyéni, közösségi és egyetemes viszonylatban. A ciklus költeményei ennek a többszintes útnak a stációi. halál, világ, önértés stb., akkor a haláltánc müfajához köthető Halál-boleróban és általában a haláltánc regiszterében megszólaló Baka-költészetben a kultúra, az irodalom különböző doméniumaiba való alászállás a lét határaival, hiábavalóságával szembesít, ugyanakkor ennek a világnak a szépség megtapasztalását lehetővé tevő képei, szerepjátékai arra hívják fel a figyelmet, hogy az így keletkező vers, kultúra érték, amely az értéktelen vagy a kétségbeejtő felmutatásával azt állítja: az alkotás, a költői nyelv a létmegértés és -felejtés egyetlen lehetséges közege, amely beavathat a létezés titkába; olyan univerzum, amely szembesít a világ természetével. Ez a szembesülés egyszerre létgazdagító, katartikus kaland és a különféle szerepekben artikulálódó fájdalmas pokoljárás egyéni, közösségi és egyetemes viszonylatban. A ciklus költeményei ennek a többszintes útnak a stációi. Müfaji, formai és motivikus sokszínüségük, a szerepváltozatok sokfélesége a Ravel, Chopin, Debussy, Bizet műveire komponált, a variációra mint kompozíciós elvre épülö boleró-ciklus összhangzattanában megteremti a polifónia harmóniáját, miközben a versek a halál felöl a létre, a kultúrára, a Baka-poétika, a költői nyelv szépségére engednek rácsodálkozni. Az egyéni, nemzeti és egyetemes létdilemmát megszólaltató költemények különböző beszélőinek szólamai a tematikai egyezésen túl a haláltánc müfajának regiszterében, az apokaliptikus világérzékelésben és az ezt artikuláló költői nyelvben válnak egységessé.

$\mathrm{Az}$ apokalipszis nagyszabású látomása a ballada müfaji hagyományához köthetö Tépéscsinálók című költemény, amely, megnyitva Baka költészetében a démoni világot láttató alkotások új sorozatát, a balladai anyagot líraian formálja. A Munkácsy

Mihály festményének egyidejüségét drámai hatású jelenetsorrá alakító ${ }^{4}$ versbeli eseményekről csak feltételezéseink lehetnek. ${ }^{5}$ A balladai homály azt sejteti, maga a költői nyelv teszi hozzáférhetetlenné a lét értelmét, titok marad, hogy van-e értelme, és ha nincs, miért nincs. 
A Kondor-festményeket idéző Angyalban a világvégi tájnak már díszletei sincsenek, a civilizáció hulladéka borítja. Az apokalipszis tárgyiasságai a Baka-vers dikciójának a megváltozását is jelentik, a szétdúlt mondatok, töredezett mégis-formák megjelenését (Lator, 2000, 172. o.). Baka költészetének arról a törekvéséről van szó, amely a tárgyias kifejezés felé való fordulásban ragadható meg (Lator, 2000,171. o.), ami a kifejezésmód tárgyiassá válását jelenti, nem objektív lírát, vagyis a maszkként megképződő beszélő közvetettsége ellenére a szerepjátszó megszólalás keretében fenntartja a lírai közvetlenség látszatát. Ennek fényében az angyal (Baka István angyalairól ld. Szigeti, 1998a, 1998b) úgy értelmezhető, mint a „,megváltozott alkotásmódban is tovább élő metafora-eszmény allegóriája” (Nagy, 2001, 41. o.), amely a „szétdúlt mondatok” között transzcendens tökéletességként a tökéletesnek gondolt nyelv eszményét őrzi. Akár a vers lírai beszélőjeként, akár az alkotó lírai én produktumaként interpretáljuk, nem törekszik arra, hogy az önreflexivitás újabb köreit megnyitva bevonja az erről szóló verset a keresztény mitológiával (csak) metaforizálható tökéletes nyelvképzetbe, sokkal inkább annak tudomásul vételéről van szó, hogy a civilizáció pokol (Szigeti, 1998a, 28. o.), és ezt a világról szerzett tapasztalatát a vers anyaga is érzékelteti úgy, hogy Baka nem alkalmazza a központozást (Nagy, 2001, 43. o.; Szigeti, 1998a, 28. o.). Bár a Baka-költészet itt még nem hajlandó lemondani az angyalról, vagyis a metaforikus versbeszédröl, amely az isteni nyelv szellemét örzi, örizheti, mégis palinodikus jellege, a költői nyelv megváltásra való képtelensége artikulálódik a modernség ellenében, arra utalva, hogy a metaforikus versnyelv ideje elmúlt (tehát Baka költészete „korszerütlen”!).

Míg az Angyalban a földi világ szeméttelep, a megváltatlan civilizáció metaforája, amelyben az angyal által megtestesített isteni nyelv, a metaforaeszmény nem jut győzelemre, addig a Halottak éjében pusztán az aktivizálódik, ami a költői nyelv számára hozzáférhető: a világ démonikus volta. A vers azt a népi hiedelmet idézi, amely szerint éjfélkor megnyílnak a sírok, a holtak visszatérnek az élők világába („,de most a deszkák széteső / tömlöcét elhagyják s birokra / kélnek veled múló idő"), de visszatérésük nem örömteli, mert a múló idő ellen harcolva létirigységük halálukra emlékezteti őket, az élöket pedig a természetként metaforizálódó halál a nemléttel szembesíti: ,hallgatjuk csontujj verdesi / eső a párás ablakot / s gyülölködőn egymást lesi / egy éjen át élő s halott". Látszólag ugyan megnyílnak, úgy tünik, átjárhatóvá válnak a lét határai, az utolsó két sorban időtlenné táguló szituáció állandósága azonban arra utal, hogy viszonylagossá válik, ki élö, ki halott, és a léthatárok - amelyek a nyelv határai is - áthághatatlanok. Marad a nyelvben, a nyelvnek való kiszolgáltatottság, és ami az Angyalban elöbb sejtelemszerü, majd nyilvánvaló veszélyérzet, az a Halottak éjében egyértelmủen artikulálódik: hiába a kísérlet a múló idő legyőzésére, nincs hír a fentről, csak a földi van, amit ellep a föld alatti, az isteni nyelvet, a révbe érést a költői nyelv démonizálódása feledteti, teljesítménye annak kimondása, hogy az ember, a világ, a nyelv a Sátán uralma alatt él, megváltódása lehetetlen.

Ezt a kozmikus méretű pusztulási folyamatot az egyetlen hasonlatot kitevő Átutazóként címü vers az egyén sorsára szabottan szólaltatja meg. ${ }^{6}$ Az önmagát utazóként meghatározó én nem azonosul az utas szereppel, hanem hasonlítja magát ahhoz. A hasonlat egyszerre jelzi a lírai énnek a szereppel való azonosulási és attól való elkülönülési vágyát, és azt, hogy saját helyzetét, szerepét a hasonló felől igyekszik megérteni. A szerteágazó hasonló képsora „egy kihült váróterem”, a „nagyváros pályaudvarára / került” átutazót körülvevő és az általa nem értett nyüzsgő világ („körülnéz és nem érti mért van itt”), amelyet az átutazó nézőpontjából látunk, miközben nyilvánvaló, hogy az átutazó képében rögzített nézőpont a lírai éné: „Mint aki egy kihült váróterem / padján riad fel téli reggelen". A késleltetett fömondat egyes szám első személyüsége retrospektív olvasatban a hasonló harmadik személyüségét az én önmegértése külsővé tételeként, külső nézőpontból történő önmegértéseként interpretáltatja az olvasóval. Az én helyzete bonyolult, 
a vers azt jelzi, hogy a világba vetett személyiség „nem vonul ki, nem menekül versbe, hiszen »átutazóként « van csupán jelen, a semmiből a tétován megnevezett céltalanságba" (Fried, 1999, 50. o.). Léte siralomvölgy, hiszen nincs benne semmilyen konkrét kapaszkodó (Máté-Tóth, 2005, 75. o.), ezért érzi magát a lírai én elveszettnek, helyzetét az okok nem tudásából fakadóan kétségbeejtőnek. Tehetetlenül várja sorsának alakulását, hiszen ha nem ismert számára az ok, akkor a következményekkel sem lehet tisztában, az oksági viszony felszámolódása vagy hiánya pedig létét abszurddá teszi. Megváltatlansága, a megváltás lehetőségéről való hallgatása és ezzel annak tagadása Baka költészete profán apokaliptikus világérzékelésének a következménye (Nagy, 2001, 207. o.). Bár a két vers léthelyzetbeli hasonlósága alapján felmerül annak a lehetősége, hogy Dsida Jenö Nagycsütörtök címü költeményéhez hasonlóan ebben a versben is profán, 20. századi Krisztus-monológot olvasunk, amely a verset a ciklus többi darabjával együtt a boleróra hangszerelt poétika későmodern költőjének (mint szerepnek) a passiójaként értelmezteti, a költeményben nincsenek egyértelmü útbaigazító jelek a beszélő kilétét illetően. A befejezés (,utazhatom tovább”) pedig kizárja a megvált(ód)ás esélyét, a versben való végső nyugalomra lelést, ehelyett a nyelvbe vetettséget állandó átmenetként, kétségbeejtő önmarcangolásként, én és a világ viszonyának állandó újraértelmezéseként, az én újabb és újabb szerepekben történő újradefiniáló gesztusaként határozza meg, ami nem lezárás, nem válaszadás, hanem nyitott kérdés, a további szerepekben való próbálkozás ígérete.

Abból kiindulva, hogy az Átutazóként címü költeményben a lírai elbeszélő aligha tud rendező elvet felfedezni a létben (Fried, 1999, 50. o.), és a folytatható út a szenvedés útja (Máté-Tóth, 2005, 75. o.), amely - esetleg - a modern költöszerep passiójaként értelmezhetö, a Vörösmarty-töredékek címü költemény úgy fogható fel, mint ennek a szerepnek a megszólaltatása. A Baka-költészetben már létjogosultságot nyert Ady-hagyományhoz köthetöen úgy olvasható a Vörösmarty-töredékek, mint (Baka-)Ady elátkozott közösségi költőszerepének végítéletet megjelenítő víziója a nemzetről, hazáról. A szerepbeli költő alakját és a közösségi, nemzeti elátkozottság gondolatát ugyanis már az Átutazóként címü költemény is felveti, amelynek nem a közösségi küldetéstudat az ihletője, hanem az odatartozás megvallása (Domokos, 1996, 32. o.): „küldetés vagy átok / sodorta erre s honnan jött hova / merült miféle múltba otthona".

A hagyományos szerepversek (Papp, 1996, 78. o.) közül külön csoportot képeznek a Vörösmarty-versek. Ahhoz a verstípushoz tartoznak, amely a magyar líra közösségi kérdéseket megfogalmazó vonulata, tehát olyan költészeteszményt képvisel, amely a közösségi költőszerep létjogosultságát állítja, illetve e szerep lehetőségeit kutatja (Kerék, 1982, 31. o.; a Vörösmarty-szerepröl ld. Baka, 2006, 271. o.). A Vörösmarty-töredékeknek már a címe jelzi ezt a törekvést. Míg Vörösmarty neve szinekdochészerüen megidézi a magyar reformkort, az 1848-1849-es szabadságharc és a forradalom bukása utáni időszakot, valamint Vörösmarty poétikájának közösségi költőszerepét, amelynek karakterisztikus vonása a nemzet biztatása és a nemzet sorsáért való aggodalom, a „töredékek” utótag befejezetlenséget és befejezhetetlenséget fejez ki. A nyelv korlátaira hívja fel a figyelmet, arra, hogy az egész felmutathatóságára nincs lehetőség, a részek, a töredékek viszont (még) olvashatók, amelyekből talán következtetni lehet az egész (nyelvi) eszményére. A cím azt is jelzi, hogy a vers(ek) beszélője különböző megszólalásmódokban megnyilvánuló közösségi költő(szerep), de a címben tetten érhető a szereppel való teljes azonosulás hiánya is, hiszen a töredékeket valaki idézi. Az idézö hagyja megszólalni a Vörösmarty-töredékeket, tehát hallgat, ugyanakkor Vörösmarty poétikájának hangja az övé (is), Vörösmartyként szólal meg, amennyiben szövegbelisége, nyelvléte a hallgatás törlődésében, a számozás, az idézés gesztusában és a citátumok egymás mellé olvasásának mikéntjében jelölődik ki. Azonosulás és eltávolítottság ez a vershelyzet megteremtésében, és a textusok idézettségében megragadható idéző maga is nyelvi képződmény, ami későmodern vonás a költeményben. Az evokáció eljárása nemcsak a címben, hanem 
a vers egészében megfigyelhető, amely a szöveg(ek) létmódját jelenti, és az interpretáció irányát is meghatározza.

Az 1. rész első szakasza a Szózat tizenkettedik szakaszának temetésképét („S a sírt, hol nemzet sűlyed el”) idézi meg áttételesen: „A koporsóra föld zuhog / A földre októberi zápor". A különbség abban van, hogy itt nincs gyászoló közösség. Az indítás tragikuma a végzet, a kilátástalanság szólamát erősíti fel, amit a sírásóval való azonosításban profanizált Úr képe is fokoz („Kocsmájából kitántorog / Az Úr a részeges sírásó”), hiszen a halál léteseményét jelenti. A blaszfémikusan láttatott „,részeges” Úr félelmetes, hiszen mivel alapállapota a részegség, a lét, a történelem uraként intézkedései kiszámíthatatlanok mind az egyén, mind a nemzet számára. A második szakaszban tovább szövődik a vers halálmetaforikája. A többes szám első személyü birtokos személyjeles „gödrünk” visszakapcsolható „A koporsóra föld zuhog” és a „sírásó” képéhez, ami jelzi, hogy itt egy közösség, egy nemzet sírjáról van szó, tehát a nemzet halálának a metaforája, $\mathrm{s}$ bár a ,pezsgőskehely”, amellyel hasonlatot alkot, előhívja az ünnep jelentéskörét, a megszemélyesítő „Vak” szó és a „Már megtelt habzó szennyes árral” apokaliptikus vízió meg is szüntetik azt, a közösség kilátástalan helyzetére utalva. Az ár összekapcsolható az első strófa zápor és a bibliai vízözön képével, asszociálva egyben Baka Szürkület címü versének nyitó képét: „A menny kilép medréből, szennyes árján / felhők - felpuffadt angyaltetemek". A poklot idéző metaforák a nemzet pusztulásának víziójává tágulnak, amely Isten groteszk mulatásának részeként, a részvéttelen világnak való felmutatásában gondolható el: „S a sírt hol nemzet süllyed el / Köszönti Isten a világra”.

A 2. részben változik a beszédhelyzet, a közösségi költő hangja egyes szám első személyben szólal meg: „Beh mélyre süllyedtem beh mélyre”. A beszédmód a népköltészet, illetve Petőfi helyzetdalainak beszédmódját idézi meg, tehát ez is a szerepjáték része, hiszen a vers nem alanyi módon szólal meg: az idézett Vörösmarty-töredék beszélőjének hangja ez. Az egyes szám első személy nem jelent a szó hagyományos értelmében vett alanyiságot. A „mélyre süllyedtem”, a „Sár minden tagom” metaforákban - utóbbi Vörösmarty $A z$ emberek című versének minősítéseit („Ez őrült sár, ez istenarcu lény!”) a beszélöre szabva individualizálja - mintha a megtébolyult én hangja hallatszana át a 19. századi versből. A 2. rész lírai énjének egyénítetten, egyes szám első személyben idézett sorsában pedig mintha az 1. rész nemzetsorsa ismétlődne meg. A jelen-múlt különbsége az időbeli elörehaladást, a nemzeti, a közösségi lét tragikusabbá válását mondja el, amely az én, a közösségi költő(szerep) alakzatába sürítve még erőteljesebb dráma. Ennek a drámának az érzelmi töltetét növeli a „mindenem minden” halmozás és „Sár mindenem minden tagom" metaforikus-metonimikus kép, amely Az élö szobor címü Vörösmarty-költemény lírai énjének kínjait is megidézi: „Szobor vagyok, de fáj minden tagom; / Eremben a vér forró kínja dúl". A beszélő kétségbeesett helyzetében megszólítja Istent. A nemzethez ugyanis nem szólhat úgy, ahogyan az Az élö szoborban történik, hiszen a nemzeti közösség pusztulóban van, tehát a közösségi költőszerep érvénytelenné válik: „Oh Isten megtalálsz-e végre / E szortyogó vak csillagon”. Nem az én keresi (az 'én'-be sürített 'mi') Istent, hanem fordítva: azt várja, hogy ő keresse meg, és váltsa meg, hiszen helyzete kétségbeejtő, bár kérdéses, van-e értelme ennek a fohásznak, ha Isten „részeges sírásó”. A bakásan vörösmartys metaforikus helymegjelölés is kifejezi a lírai én kilátástalanságát: a „szortyogó” melléknévi igenév emberi hangja összekapcsolódik $A$ vén cigányból ismert, a bolygót metaforizáló „,vak csillag” képével, amely Vörösmarty versében úgy jelenik meg, mint az önmaga vigasztalására való felszólítás része, tehát mintegy kívülről mutat rá a beszélő, itt azonban a közelre mutató névmás azt fejezi ki, hogy a beszélő a nyomorúságban közelröl érintett. A második strófában az elállatiasodást kifejező apokaliptikus táj részletei tárulnak fel az Istenhez szóló fohász részeként (,hüllőbőrü réteken”; „dülledt hüllőszem tavak”), és úgy tünik, nagyobb esélye van annak, hogy az énre meredő világ, a metaforikus „hüllőszem”-ek az énnel kapcsolatba kerülje- 
nek, mint annak, hogy az én kapcsolatot létesítsen azzal, akihez fohászkodik. A nemzet, az egyén sorsának irracionális intézőjét „Égi Vak”-nak nevezi, és azt kéri, mentse meg, azaz vakítsa meg, hogy ne lássa a világot, mert akkor legalább számára az megszűnik létezni. A „Vakíts meg engem Égi Vak” sor mintha József Attila Bukj föl az árból címü verse következő sorainak átírása lenne: „Ijessz meg engem, Istenem, / szükségem van a haragodra. / Bukj föl az árból hirtelen, / ne rántson el a semmi sodra.” A József Attila-i sorok Baka versében a démonikus létérzékelés kifejezőivé válnak: kiábrándultságából adódóan az apokalipszistől, a semmitől való megmenekülés helyett a semmibe való menekülést kéri a lírai én. A József Attila-vers lírai énje büntetést kér Istentől, ami hite szerint megváltást jelenthetne, itt azonban nemcsak az jelenti a büntetést, hogy az „Égi Vak" nem cselekszik, hanem az is, hogy a beszélő nem tud hinni már egy olyan isteni képességekkel rendelkező erő létezésében (Máté-Tóth, 2005, 73. o.), aki őt észrevenné, hisz ha van is, a vég felé tartó világ uralma alatt él ő is. A harmadik szakasz Az emberek címü költemény utolsó két sorát megfordítva idézi („Nincsen remény nincsen remény / Az emberfaj tudom tudom / Tudom sárkányfogvetemény”), és megtoldja egy közbevetéssel („...tudom tudom / Tudom...”). A „,tudom” háromszori megismétlésével a beszélő szavai önnön idézettségükben visszautalnak saját pretextusukra. A módosítás kiemeli a lírai én tudatosságát, belenyugvását, rezignált keserüségét, és a világban benne levőként támasztja alá saját pretextusának általánosító igazságát. Szöveg mutat rá a szövegre, mondván: semmi nincs a nyelven kívül. Az utolsó strófa is a nyelv uralmát jelző önidézés, az első szakasz második sorának („Sár mindenem minden tagom”) variációja („Minden napom sár mindenem"), amely azt érzékelteti, hogy az én sárkányfogléte állandósul az időben. A „Meglelsz-e engem Istenem”, a beszélő lemondó kérdése ezért valójában belső monológ, hiszen az „Égi Vak”-hoz egyszerre társul a fehér bot által a vakság és a vakító fény jelentése. A „Fehér bot fénnyel” ugyanakkor az énhez is tartozhat. Eszerint ő az, akit fehér bottal kellene megtalálnia Istennek. Ez azt is jelenti, hogy a lírai én kérése meghallgatásra talált, és hasonult Urához, de így, a vakság állapotában mindketten meg is szünnek egymás számára. Törlődik tehát a versből mind az én, mind az Isten.

A 3. rész első szakasza négy kipontozott sor. Ez a szakasz grafikusan is megmutatja a töredékjelleget. A szakasznak a szerkezetben betöltött jelentőségén túl a kipontozott résznek a hallgatás artikulálásában van szerepe. Értelmezhető úgy, mint a léte legmélyére jutott lírai én elcsuklásának momentuma, mert nem tudja a sírás miatt továbbmondani a szöveget, ugyanakkor értelmezhető az Isten versböl való törlődésének és az Istenhez hasonult én törlődésének grafikus metaforájaként is (a pontsorok mint metaforák). A csend a törlődött énre és Istenre mutat vissza. Úgy is interpretálható ez a szakasz, mint a cím kapcsán értelmezett Vörösmarty-töredékeket idézö én felejtésének a lenyomata, vagy mint a „töredékek” értelmezése kapcsán felvetett nyelvbeli rögzíthetőségnek és/vagy a szerepteremtésnek a kudarca. Ebből a csendből szólal meg a vers utolsó szakasza, amelynek első sora („És bár szemében gyászköny ül”) az „annak ellenére” jelentésű „,bár” szóval módosítja a pretextust. A Szózatban a negatív jövőkép egy lehetőség felvillantása arról, hogy ha el is kell pusztulnia a magyarságnak, az - annak hősi múltja folytán - a világ részvétteljes jelenlétében történik. Baka versében a „bár” szócska a tragikus nemzethalál-víziót groteszkbe fordítja át, amelyben a „gyászkönny” megjelenése a megjátszottság része. A vers blaszfémikus befejezése (hiszen a „megkönnyebbül” egyszerre jelent hányást, vizelést vagy szellentést) azt sugallja, a nemzet halála örömünnep a világ számára, és ez azért következhetett be, mert ő maga a hibás, hogy nem fogadta meg a Szózat beszélőjének tanácsát. Ezért lehet a róla szóló versbeszéd szarkasztikus. Az utolsó szakasz temetkezés motívuma a Szózattal összehasonlítva nem jóslatként, hanem történő folyamatként olvasható, megidézve a groteszk-démoni haláltánc látomását, előreutalva a cikluszáró Halál-boleróra.

Miután törlődött a vers textusából Isten, akihez az én folyamodott, és aki ezáltal maga is törlődött, a menekülés következményeként lehetetlenné válik az egyes szám első sze- 
mélyü versbeszéd, a 'te' megszólítása, tehát lehetetlenné válik a közösség és a közösségi költőszerep nyelvbelisége is. Ezért lehet csak töredékekben beszélni róla, vagy még úgy sem. Ezzel magyarázható a záró szakasz személytelensége, amely az első, pontokból álló szakasz csendjét és az 1. rész személytelenül megjelenített apokalipszisét írja tovább és zárja le. Önmaga szerepteremtő gesztusa fölött is ítéletet mond a szöveg, bejelentve a közösségi költőszerep konstruálhatóságának kudarcát. A groteszk vízió így a nyelv pusztulásának látomásaként is olvasható. A dantei pokol egyre mélyebb körei felé tartva, a Vörösmarty-töredékekben a már korábban sajáttá tett, a Fegyverletétel című ciklus verseiből, a Háborús téli éjszakából, a Trauermarsch-ból, a Tépéscsinálókból vagy más versekből ismert apokaliptikus hagyomány borzalma tárul fel: most már egyre gyakrabban úgy, hogy a nyelv is sérül - töredékessé válik vagy törlődik. Éppen ezért nemcsak a keletkezés tényeivel ${ }^{7}$, hanem nyelvi-stiláris érvekkel, az épülö-építkező szerepjátszó poétika belső logikájával is magyarázható, hogy miért keres Baka István költészete újabb szerepeket, maszkokat a megszólalásra mind a cikluson belül, mind a közösségi-nemzeti tematika újramondására Liszt Ferenc maszkjában.

Miután a Vörösmarty-törekékekben törlödik Isten, és töredékessé válik, illetve helyenként törlödik a nyelv, a Vezeklés (Agatha Fasset: Bartók amerikai évei címü könyve alapján) címü szabadvers egyes szám első személyü lírai története az alcím által kijelölt olvasmányélmény, intertextuális utalás révén bírja szóra a nyelvet, amely a központozás hiánya, a soráthajlások, az egyenetlen hosszúságú, a kis- és nagybetủvel szedett sorok grafikai különbségei folytán továbbviszi az előző költemények nyelvére is vonatkozó töredékes jelleget. Az apokaliptikus hangszerelésű nyelv által teremtett versvilág lírai története így válik a befejezés - a költemény egészét didaktikussá tevő - látomásában a vég felé haladó egyéni és (a Bartókra való utalás révén) az egyéniben a közösségi lét, a kultúra értelmetlenségét is hordozó példázattá. Ebben a (vers)világban az egyén és a közösség üdvössége elszalasztásának utólagos tudatosulása miatti fájdalmat még tetézi a materializálódott Isten-nyomok által helyettesített Isten vissza-visszatérő emléke. Így lesz az egyéni és közösségi lét, tágabb kontextusban a kultúra létmódja a vezeklés. A vezeklő szerepében konstruálódik meg az én a Caspar Hauserben és a Hurok-szonettben is, amelyekben - miután az előző versek felmondják a romantikus közösségi költőszerep érvényességét - az egyén önmaga felé fordul, a lét, vagyis későmodern értelemben a nyelv határait méri fel, hiszen a nyelv az én létmódja.

A Caspar Hauser címü költemény a számvetés-összegzés költői gesztusa mellett a Vezeklés címü vers léthelyzetét is továbbviszi ${ }^{8}$, különböző mitologikus hagyományok számüzetés motívumát parafrazálva (Nagy, 2001, 101. o.): „Én nem tudom ki küldött e világba / a tömlöc jó volt vaknak lenni jó / most bámulok a menny hideg falára / túl messzi túl kék és túl szétfolyó". Northrop Frye szerint a mozgásszabadság legdurvább megsértése a börtön ${ }^{9}$, amely Bakánál ironikusan a létezés elviselhetöségét jelenti a világba vetettséggel szemben (Fried, 1999, 57. o.). Az egyes szám első személyben beszélő Caspar Hauser perspektívaszükítő szólamában a világ nem csupán a számüzetés, hanem a kozmikus magányosság színhelye is, a világdrámáé, amelyben nincs lehetőség a cselekvésre, a sors irányítására (Fried, 1999, 54-55. o.): „én nem tudom ki száműzött e földre / [...] // én nem tudom mivégre / az alkony-dráma és a virradat / komédiája minden napja éje / e létnek”. S bár a versbeli Caspar Hauser számára nincs megváltás, a számüzetéslétből nincs visszatérés (,én nem tudom ki volt ki engemet / kiragadott a semmiből a jóból / hogy árnyak közt mulandó árny legyek") az ironikusan értett édeni létállapotba, a tömlöcbe, a vers beszélőjének szerepét kijelölő „én nem tudom" szakaszonkénti megismétlése arra utal, hogy nincs szó passzivitásról. A lírai én „rádöbbenése a lét könyörtelen törvényére, a változatlanságra és változtathatatlanságra valójában nem tekinthető egyértelmüen vereségnek: a sorsnélküliség fölismerése annak átlépése, ennek következtében a szüntelen ismétlődő jelenségek, a kozmikus idő 
rideg körforgása legalább a saját sorsától való elhatárolódást eredményezik" (Fried, 1999, 55. o.).

Caspar Hauser árnylétével rokon a Hurok-szonett beszélöjének helyzete is. Létbe vetettsége nyelvbe veszettség („Erdő vagyok - eltévedek magamban”), labirintuslét, akárcsak a Post aetatem vestramban vagy a Thészeuszban (Nagy, 2001, 79. o.). Nem véletlen, hogy a töredezettség, a nyelv apokaliptikus természetének ellensúlyozásaképpen Baka István költészetének ezen a pontján talál rá a nyelvbe zártságot mutató, ugyanakkor a nyelvet mint az egyetlen élhető létet jelentő müformára, a szonettre (Szigeti, 1996, 109. o.). A Hurok-szonett kevésbé emlékeztet a szokott szonettformára, inkább a sonettesse formahagyományához igazodik (strófaszerkezete 3-3-4-4 vagy mint Bakánál: 4-3-3-4): ,a két kvartett fogja közre a két tercettet [...], ráadásul Baka a tercettet is szétdarabolja: kétsoros és egysoros szegmentumokra bontja öket. A verscím tehát [...] költői magatartásra sugalló szerepre utal: a létbezártság élményére, amelynek [...] önkörét hangsúlyozza erőteljesen a tercetteknek a kvartettekbe szorítottsága." (Szigeti, 1996, 110. o.) Amennyiben az intertextuális utalásként felfogható, Dante Isteni színjátékából ismert erdő motívuma mint a lét labirintusa nyelvi képződmény, amellyel az én azonosítja magát („Erdő vagyok”), akkor a vers a hurokként viselkedő nyelv megnyilvánulása, ${ }^{10}$ amely labirintusként teremti a szonettet, a káoszból a rendet, az isteni nyelv eszményét, hogy fenntarthassa az én nyelvben, kultúrában való bolyongását, hiszen ez a feltétele a vers (önreflexióként a Hurok-szonett címü költemény), a kultúra meglétének még akkor is, ha csak önmaga labirintuslétét, démonikus karakterét képes felmutatni.

A tökéletes költői-isteni nyelv eszményéért folytatott küzdelem, ennek a küzdelemnek a kudarcáról számot adó, ezért a kultúrát olykor apokaliptikus víziókban láttató míves költemények összegződése a zenei ihletésü Halál-boleró. Aktivizálva a nyelv önreflexív képességét, a Tépéscsinálók és a Vörösmarty-töredékek címü versek képi világának előzménye után ${ }^{11}$ azt mutatja meg, hogy a halál a költői nyelvet meghatározó minőség, és eljut addig a pontig, hogy a költői nyelv mint matéria a képek formálódását, formavilágát meghatározó verszene által váljék a kísértetiesség hordozójává. A Halál bolerójának hangja félelmetes, de bódító lehet, ha eljuthatna a szerepbeli költő a Hurok-szonett labirintusából a nyelven túliba, egyesülve az istenivel, a határtalannal.

A cím egy középkori müfajra utal, a dance macabre hagyományára, de nem szokott formáját követve, ugyanis ez a haláltánc boleró, a vers szerkezet és metrikai felépítés tekintetében a boleró stílusát követi. ${ }^{12}$ A Beethovent, Chopint, Ravelt vagy Moskovskit megihlető boleró müfajának tárgya a haláltánc középkori hiedelemvilága, amely szerint éjfélkor a holtak kilépnek a sírjukból, és hajnalig táncolnak. Így a vers tárgyát tekintve nemcsak a halálról, hanem a haláltáncról is szól, tehát a nyelvben megragadható hagyományról. Ezáltal a mű egyszerre köthető a boleróhoz (pl. Ravel: Boleró), a haláltánc müfajához, ${ }^{13}$ a haláltánchoz közeli vámpírtörténetekhez (pl. Baka István: A kisfiú és a vámpírok, Roman Polański: Vámpírok bálja) és Mihail A. Bulgakov A Mester és Margaritájából a Sátán báljához. A mű megidéz Liszt-müveket is, előreutalva a Liszt Ferenc-ciklus verseire: Mefisztó-keringő, Haláltánc, Csárdás macabre, Funérailles stb. A versnek a haláltánc, a boleró müfajához köthető intertextuális játéktere és a költemény önreflexivitása arra hívja fel a figyelmet, hogy ennek a versnek a hagyományhoz való viszonya összetettségében értelmezendő, vagyis azt gondolom, a vers képi világára, lírai történésére vonatkozó reflexión túl (Szigeti, 2005, 86. o.) a költői nyelv müködésére kell figyelnünk. Az ismétlődéseken, variációkon és fokozáson át hömpölygő démonikus folyamat ugyanis azt a nyelvi történést metaforizálja, amely a költői nyelv müködésének mikéntjére, a hagyományhoz való viszonyára enged rálátni. A boleróként metaforizált költői nyelv haláltáncát járja, vagyis arra törekszik, hogy leszámoljon minden rárakódással, a hagyományhoz való viszonyulásból létrejövő tragikummal, iróniával, groteszkkel, hogy végül a verszene egyre tébolyítóbb mámorában eljusson a nyelven 
túliba, amely lehet a nyelv utáni isteni, harmonikus állapot és/vagy egy új költői nyelv felfedezésének fenséges pillanata. Az utolsó szakaszban azonban ez az ígéret beteljesületlen marad, elhallgat a Halál által írt vers, és marad büntetésként-bünhődésként a szó („Száll a pimasz szó. / Újra hazudja a létet.”), amely az elérhetetlen isteni nyelvet létezőnek, a nyelv labirintusába való vetettséget hazugságnak minősíti, egyben a pokoljárás újabb dimenzióinak megismerésére kárhoztatva, vagyis újabb szerepek felé csalogatva az ént. A vers palinodikus jellegü befejezése azt is előrevetíti, hogy (Bakánál) a költői nyelv végzete a hazugságlét, amely a szerepekben való létesülés révén továbbra is éppen azt fogja elfedni, ami felé törekszik: az isteni nyelvet. Ebben az összefüggésben a Halál-boleró egyrészt úgy értelmezhető, mint a költői szó kudarca, az eddig megalkotott és az ezután létrejövő szerepversek miatti büntudat és bünbánat, másrészt felkészülést jelent a további költői tevékenységre mint hiábavaló küzdelemre (Szigeti, 2005, 88. o.). Így lesz a vers, a költészet a teremtés értelmének a tagadása (Szigeti, 2005, 93. o.), ami paradox módon igent mond a költészetre, a további versekre, szerepekre, és ez mégiscsak a Baka-poétikának a költői szó erejébe vetett hitéről tanúskodik.

\section{Irodalomjegyzék}

Baán Tibor (1991): Szerepválaszok. Baka István: Égtájak célkeresztjén. Új Írás, április. 115-121.

Baka István (2006): „Fehér és barna szárnyak”. Beszélgetőtárs: Gacsályi József. In: Baka István müvei. Publicisztikák, beszélgetések. Tiszatáj Könyvek, Szeged. 266-280.

Domokos Mátyás (1996): Emlékek célkeresztjén. Tiszatáj, 9. sz. 26-39.

Fried István (1999): Árnyak közt mulandó árny. Baka István verse Caspar Hauserről. In: uő: Árnyak közt mulandó árny. Tanulmányok Baka István lírájáról. Tiszatáj Könyvek, Szeged. 42-62.

Kerék Imre (1982): Kétely és hit között. Baka István: Túzbe vetett evangélium. Napjaink, 1. sz. 31.

Lator László (2000): Baka István égtájai. Baka István: Égtájak célkeresztjén. In: Füzi László (szerk.): Búcsú barátaimtól. Baka István emlékezete. Nap Kiadó, h. n. 166-174.

Máté-Tóth András (2005): Baka Istene. Tisztelgő tanulmány halálának 10. évfordulójára. Tiszatáj, 9. sz. $68-78$.

Nagy Gábor (2001): „... legyek versedben asszonánc”. Baka István költészete. Kossuth Egyetemi Kiadó, Debrecen.

Nagy Gábor (2004): A nemzeti közösség sorsértelmezése Baka István költészetében. Forrás, 12. sz. 53-79.
Papp Ágnes Klára (1996): Szépség és harmónia hermeneutikája. Baka István Tájkép fohásszal címü kötetéröl. Nappali Ház, 4. sz. 75-79.

Szigeti Lajos Sándor (1996): „Metaforákkal tele, megjelenik a líra szelleme". A palackba zárt szonett szabadulása. Tiszatáj, 9. sz. 107-114.

Szigeti Lajos Sándor (1998 a): „Iszonyú mindegyik angyal"'(?). (A civilizáció poklából a belső végtelenségbe). Új Dunatáj, június. 24-40.

Szigeti Lajos Sándor (1998 b): (De)formáció és (de) mitologizáció. Baka István angyalainak tündöklése (és bukása?). Tiszatáj, 7. sz. 71-92.

Szigeti Lajos Sándor (2005): Dance macabre. In: Uő: Verssor(s)ok. Széphalom Könyvmühely, Budapest. 82-102.

Szőke Katalin (2000): A költő és a müfordító szerepcseréje. Baka István költészetének orosz kulturális kódja. In: Füzi László (szerk.): Búcsú barátaimtól. Baka István emlékezete. Nap Kiadó, h. n. 110-121.

Valastyán Tamás (2006): Apokrif alázattal és vakmeröséggel. In: Bombitz Attila (szerk.): „Égtájak célkeresztjén”. Tanulmányok Baka István müveiröl. Tiszatáj Könyvek, Szeged. 99-111.

Vörös István (1997): Baka István: Tájkép fohásszal. Kritika, 1. sz. 42-43. 


\section{Jegyzetek}

${ }^{1}$ A tanulmány Baka István Tájkép fohásszal (Jelenkor Kiadó, Pécs, 1996) címü gyüjteményes kötete mint a szerzői kanonizációs gesztus révén az életmüvet lezártnak és véglegesnek felmutató, újraértett költői testamentum recepcióesztétikai alapú interpretációjának egy részlete.

${ }^{2}$ Baka István költészetének átíró, a hagyományt újraértelmező karakteréről és annak értelmezhetőségéről ld. Fried, 1999, 43-44. o.

${ }^{3}$ „A költői nyelv tágas »élet-elvü« szóöbleibe igenis beszivároghat a halál kétségbeesésének jajkiáltása. [...] A poétikai megnevezéseknek a »közös lét« számára vizionált és fikcionált szóképeit árnyalhatja a hallgatás, a csend egyénekre szabott, váratlanul az emberre ráomló hatalma. És gyönyörü alakzatokat rajzolhatnak ki." (Valastyán, 2006, 103. o.)

${ }^{4}$ Baka úgy alakítja drámai jelenetsorrá a Munkácsy-kép jelenetét, hogy strófánként visszatér az indító képhez, „hogy magából a képből bontsa ki a »hollófehér, alkonybarna « vérpiros színekben megelevenedő látomást, mely az idő múlásának megérzékítésével [...] fokozza a drámaiságot" (Baán, 1991, 119. o.).

${ }^{5}$ „Háború lehet, hiszen »ki a fiát siratja, ki a férjét«. A vers ismétlésekkel halad elöre, egyre fokozva a feszültséget és a várakozást. A balladai sejtetés és a baljóslatúság révén a démonikus alkotások közé tartozik a vers”, és a halál „világnyi méretüvé” tágul (Nagy, 2001, 98. o.): „,a bokrok bordáit szél kardlapozza / és fölfröccsen az Isten ősz ölébe / a férfiak a föld fekete vére".

${ }^{6}$ A vers első harminchat sora a kifejtett, felsorolásokból, ismétlésekből álló, a hasonlítottal együtt egy többszörösen összetett mondatot kitevő hasonló, az utolsó hat sor pedig a hasonlított.
${ }^{7}$ Nagy Gábor $(2001,151$ o. ) csak a keletkezés felől, tehát nem eléggé körültekintően magyarázza ezt a kérdést.

${ }^{8}$ „Baka István a maga költészetének figurái mellé iktatja be Caspar Hausert, méghozzá olymódon, hogy a Hauser-»legendárium« historikumában válogatva, mellőzi a történetnek mindazon elemeit, amelyek nem a semmiből a semmi felé tartó »utazást« tematizálják, eszerint nem látszik tudomást venni azokról a változatokról (így Georg Trakléról vagy éppen Juhász Gyuláról), amelyek nem a világba vetettség értelmetlenségét, szinte abszurditását gondolják újra." (Fried, 1999, 51. o.) A továbbiakban Fried azokat az elöszövegeket veszi szemügyre, amelyekre utalhat a Baka-vers: Verlaine: Gaspard Hauser chante (Caspar Hauser dalol, Szabó Lörinc ford.); Jacob Wassermann: Caspar Hauser.

${ }^{9}$ Northrop Frye (Az Ige hatalma. Európa, Bp., 1997, 234. o., idézi: Nagy, 2001, 101-102. o.) az elsődleges emberi érdekek négy csoportját különíti el. A negyedik csoportba tartoznak a szabad mozgás érdekei.

${ }^{10}$ Szőke Katalin $(2000,118$. o.) A költő és a müforditó szerepcseréjében mutat rá, hogy a versben Tarkovszkij költészetének hatása is müködik.

${ }^{11}$ Képi megformáltság és kompozíció tekintetében a Halál-boleró rokonságot mutat a Trauermarsch-sal és a Mefisztó-keringővel is, a Baka által is fordított C. M. Bellman dalainak hatására a Yorick-ciklus előzményének is tekinthetö (vö. Nagy, 2004, 64-65. o.).

${ }^{12}$ Szigeti Lajos Sándor (2005) Dance macabre címü tanulmányában elemzi a vers intertextuális játékterét, stílusbeli, szerkezeti, zenei, verstani összefüggéseit.

${ }^{13}$ Szigeti Lajos Sándor (2005, 85., 89-90. o.) számos irodalmi és nem irodalmi példát sorol fel a haláltánc müfajára. 